\title{
EFFECT OF Cayratia trifolia L (Domin) EXTRACT ON REDUCED EXPRESSION OF MATRIX METALLOPROTEINASE-9 (MMP-9) AND VASCULAR ENDOTHELIAL GROWTH FACTOR -A (VEGF-A) IN WHITE RATS WITH BREAST CANCER
}

\author{
Devi Cynthia Dewi, ${ }^{1}$ I Ketut Sudiana ${ }^{2}$ \\ ${ }^{1}$ Master of Immunology, Universitas Airlangga \\ ${ }^{2}$ Department of Anatomic Pathology,
}

\begin{abstract}
ABSTRAK
Angka kejadian kanker payudara setiap tahun mengalami peningkatan, salah satu upaya untuk mengatasi kanker payudara adalah dengan terapi anti-angiogenesis yang berfungsi untuk menghambat pertumbuhan dan metastasis dari sel kanker, proses angiogenesis dan metastasis pada sel kanker sangat berhubungan dengan ekspresi Matrixmetalloproteinase-9 (MMP-9) dan Vascular endothelial growth factor (VEGF). Untuk menurunkan metastasis pada sel kanker bisa dilakukan dengan pemberian ekstrak tumbuhan Cayratia trifolia L (Domin), mengandung senyawa aktif Resveratrol, Delphinidin/Malvidin dan Quercetin. Kandungan senyawa kimia dari tumbuhan ini memiliki efek imunomodulator, yang berpotensi menghambat angiopoitin dan FGF serta angiogenesis menurun, neovaskularisasi menurun sehingga metastasis pada sel kanker dapat dihambat.Tujuan dari penelitian ini adalah untuk menganalisis pengaruh ekstrak etanol tumbuhan Cayratia trifolia L (Domin) terhadap penurunan ekspresi Matrixmetalloproteinase-9 (MMP-9) dan Vascular endothelial growth factor (VEGF) pada tikus model kanker payudara. Pada penelitian ini menggunakan metode eksperimental murni laboratorium (True Experimental) dengan rancangan penelitian Randomized Post Test Only Control Group Design. Penelitian ini menggunakan model hewan coba betina Rattus Sprague dawley sebanyak 30 ekor yang dibagi dalam 3 kelompok. Pada kelompok penelitian ini K0 jumlahnya 5 ekor, KI jumlahnya 6 ekor, dan KP jumlahnya 8 ekor. Kelompok KP adalah hewan coba kanker payudara yang diberi ekstrak Cayratia trifolia sebanyak $300 \mathrm{mg} / \mathrm{kgBB}$ selama empat minggu. Untuk membuat model hewan coba kanker peneliti menggunakan DMBA dengan dosis $10 \mathrm{mg} / \mathrm{kgBB}$ diberi secara oral. Berdasarkan analisa statistik dari MMP-9 dan VEGF-A, di dapat hasil antara kelompok KI dengan KP menunjukkan suatu perbedaan yang bermakna $(p<0,05)$. Pemberian ekstrak tanaman Cayratia trifolia secara oral dapat menurunkan jumlah sel yang mengekspresikan MMP-9 dan jumlah sel yang mengekspresikan VEGF-A. Ekstrak etanol tumbuhan Cayratia trifolia L (Domain) dapat menurunkan ekspresi Matrixmetalloproteinase-9 (MMP-9) dan Vascular endothe lial growth factor (VEGF) pada tikus putih model kanker payudara. (FMI 2016;52:35-41)
\end{abstract}

Kata kunci: kanker payudara, matrixmetalloproteinase-9, Vascular Endothelial Growth Factor, Cayratiatrifolia L (Domin)

\begin{abstract}
The number of cancer cases in every year has increased. One effort in reducing breast cancer cases is by using anti-angiogenesis which could prevent the growth and metastasis of cancer cells. Xxx the process of angiogenesis and metastasis in cancer cells are associated with the expression of Matrixmetalloproteinase- 9 (MMP-9) and Vascular Endothelial Growth Factor (VEGF). To reduce metastasis in cancer cells, it can be performed by giving plant extracts Cayratiatrifolia L (Domin), containing the active compound Resveratrol, delphinidin/malvidin and Quercetin. The content of the chemical compound of these herbs has immunomodulatory effects, which could potentially prevent angiopoitin, FGF and decrease angiogenesis and neovascularization. So, the metastatic cancer cells can be inhibited. Objective to analyze the effect of the ethanol plant extract Cayratiatrifolia L (Domin) toward the reduction of Matrixmetalloproteinase Expression.-9 (MMP-9) and Vascular Endothelial Growth Factor (VEGF) on white rat of breast cancer models. This study used pure experiment laboratory (True Experimental) with Randomized design study. Post Test was only applied on Control Group Design. This research used experimental female animal Sprague Dawley Rattus which consisted of 30 individuals divided into three groups, from aged 30-40 days. In this research the number of K0 consisted of 5 individual, $6 \mathrm{Kl}$ and $8 \mathrm{KP} . \mathrm{KP}$ is a group of experimental animals with breast cancer who were given Cayratiatrifolia extract as much as $300 \mathrm{mg} / \mathrm{kg}$ for four weeks. To create animal cancer models, the researcher used DMBA a dose of $10 \mathrm{mg} / \mathrm{kg}$ given orally. The measured variables were cells expressing Matrixmetalloproteinase-9 (MMP-9) and Vascular Endothelial Growth Factor (VEGF), differential test applied in this study is Manova. Results based on the statistical analysis of MMP-9 and VEGF-A, between the KI to KP showed a significant difference $(p<0.05)$. Cayratiatrifolia plant extract orally can decrease the number of cells that express MMP-9 and the number of cells that express VEGF-A. The ethanol extract of plants Cayratiatrifolia L (Domain) can reduce the expression Matrixmetalloproteinase-9 (MMP-9) and Vascular endothelial growth factor (VEGF) on white rat of breast cancer models. (FMI 2016;52:35-41)
\end{abstract}

Keywords: breast cancer, matrixmetalloproteinase-9, Vascular Endothelial Growth Factor, Cayratiatrifolia L (Domin).

Correspondence: Devi Cynthia Dewi, Postgraduate Program, Master in Immunology, Universitas Airlangga, Campus B, Jalan Airlangga 4-6 Surabaya 60286, Indonesia. Email: devicynthia07@yahoo.co.id 


\section{INTRODUCTION}

The incidence of cancer each year has increased. In Indonesia, breast carcinoma is the second most cancer after cervix carcinoma and more than $50 \%$ of patients with breast carcinoma was found in an advanced stage (Kurnia et al 2009). One effort to overcome cancer is to harness that type of medicinal plants as examples of plants galing (Cayratia trifolia). The chemicals contained by Cayratia trifolia is stilbenes (such as: piceid, resveratrol, viniferin, and ampelopsin), kaempferol, quercetin (Kumar et al 2011). Some researchers report that kaempferol is a chemical that is used as an anti-angiogenesis in ovarian cancer therapy (Luo et al 2009). In malignant cancer in the gland structures are organized as colorectal epithelium. Growth and meta-stasis require angiogenesis process. VEGF (Vascular endothelial growth factor) is also called VPF (vascular permeability factor) is the most important proangiogenic factor and most widely expressed in various types of cancer.

Matrix Metalloproteinase-9 (gelatina se B) is a member of the metalloproteinase family that plays a role in degrading the basement membrane components, the first important barrier intruded by cancer cells when starting the invasion of other tissues. This enzyme plays a role specifically in the development and invasion of some cancers. MMP-9 levels high will cause tissue degradeation process becomes faster and thus the process of cancer cell invasion would take place more easily (Hemati et al 2010).

Cancer cells inhibit the activity of macrophages, with MAF (Macrophage Activating Factor) activity triggers macrophages TAM and CTL (Cytotoxic T-Lym phocite)NK cells and NK cells (Natu ral Killer Cell) secrete cytokines INF- $\gamma$ and IL-10. TAM (tumor associated magro phage) triggers the secretion of MMP9. As well as cancer cells also secrete MMP-9 and TAM also secrete VEGF, angiopoitin, and FGF. Cancer cells require nutrients and cancer cells exit the extracellular matrix degradation and migration of malignant cells. Cancer cells produce VEGF contribute to neovascularization of tumors that respond to improve the delivery of nutrients and oxygen needs. It is necessary for the survival of cancer cells, resulting in metastasis in cancer cells.

The discovery of anti-angiogenesis is necessary to inhibit the growth and metastasis of cancer cells, to reduce metastasis in cancer cells can be performed by administering a compound such as flavonoids, these chemical compounds contained in plant Cayratia trifolia L (Domin), containing the active compound
Resveratrol, delphinidinmalvidin and Quercetin. (Tapas et al 2008, Road et al 2008, Singh et al 2012).

Plant Cayratia trifolia $L$ (Domin) as the test material containing the active compound Resveratrol, dolphinidinmalvidin and Quercetin. The content of chemical compounds from this plant have immunomodulatory effects, which potentially inhibit angiopoitin and FGF as well as decreased angiogenesis, neovascularization is decreased so that the metastatic cancer cells can be inhibited. Until now the influence Cayratia trifolia $L$ (Domin) on the expression of VEGF and MMP-9, especially in the mechanism of angiogenesis and metastasis in cancer cells is still unknown. The study was conducted on rats model of white cancer by inducing material carcinogen DMBA (7,12-Dimethylbenz (a) anthrax cene) dose of $20 \mathrm{mgkg}$ body weight 2 times a week orally (intragastric) for 5 weeks (Pratiwi et al 2009). This study investigated the effect of ethanol extracts of plants Cayratia trifolia L (Domin) to decrease the expression of Matrix metalloproteinase-9 (MMP-9) and Vascular endothelial growth factor-A (VEGF-A) in the rat model of breast cancer.

\section{MATERIALS AND METHODS}

This research is a purely experimental research laboratory (true experimental) with the study design Randomized Post Test Only Control Group Design. Research conducted at the Electron Microscope Unit and Integrated Medical Laboratory, Faculty of Medicine, Universitas Airlangga, Surabaya for immunohistochemical examination. The research unit is in the form of slide preparation derived from normal breast tissue and tissue of white mice white mouse models of breast cancer breast cancer, with the female gender Spague Dawley strain as much as 30 individuals were divided into 3 groups. K0 without DMBA-induced group, while group $\mathrm{K} 1$ and $\mathrm{KP}$ carcinogenic materials DMBA induced a dose of $20 \mathrm{mgkg}$, dissolved in $1 \mathrm{ml}$ of corn oil, and orally (intragastric) 2 times a week for 5 weeks. Sampling techniques done by random allocation. Ya ng criteria must be met are the criteria for inclusion and exclusion criteria.

\section{Immunohistochemical examination procedure (method Steptavidin-Biotin)}

How to color the MMP-9 is the network that has been cut with microtome that have been placed on the object and then do deparaffinisasi glas, which is interesting eliminating paraffin that is in the network. The way to enter the incision the network respectively into xylol 3 times (a ': 2 minutes), after which it then inserted successively into ethanol with concentrations gradually 
decline starting from $100 \%$ ethanol (3 times) a ': 1 minute, then $95 \%$ (2x) a': 1 minute later $90 \%, 80 \%$ and $70 \%$ respectively $1 \mathrm{~min}$, then washing with tap water about 5 minutes, then put peroxide $3 \%(30 \mathrm{~min})$ to remove endogenous peroxidase. Then do the washing with water, then wash with aquadestilat, then PBS respectively 2 minutes. Furthermore then put into a solution of $0.025 \%$ trypsin in PBS $(\mathrm{pH} 7.4)$ for 6 minutes at $37^{\circ} \mathrm{C}$. Then wash PBS three times (a ': 2 minutes), then put in the primary monoclonal antibody (mouse anti-Rat MMP-9 and VEGF-A) for 30 minutes, then wash with PBS three times (a': 2 minutes), subsequently incorporated into the secondary monoclonal antibody is Rabbit anti mouse biotinylated labeling for 30 minutes. Then washed with PBS 2 times (a ': minutes), then successively put into streptavidinHRP: label 30 minutes, washed with PBS three times (a': 2 minutes), was added to the substrate chromogen: 5 minutes (DAB solution ), washed with PBS three times (a ': 2 minutes), then rinsed with aquadestilat, added Mayer Hematoxylin: 6 minutes, washed with running water, and finally in-mounting and observationreading results at light microscope magnification $400 \mathrm{x}$ in 10 field of view (Mayer \& Walker 1990, Sudiana 2005).

\section{RESULTS}

The number of cells that express

Matrixmetalloproteinase-9 (MMP-9) and Vascular Endothelial Growth Factor (VEGF-A).

Normality test data on the number of cells expressing Matrixmetalloproteinase-9 (MMP-9) and Vascular Endothelial Growth Factor-A (VEGF-A) in each treatment group using Kalmogorov-Smirnov $\mathrm{Z}$ indicates that the data obtained normal distribution.
Table 1. Data distribution on MMP-9 and VEGF expression in mammary tissue of Sprague dawley Rattus

\begin{tabular}{cccc}
\hline Groups & N & Mean & SD \\
\hline K0 - MMP-9 & 5 & 0.00 & 0.00 \\
KI - MMP-9 & 6 & 22.51 & 6.03 \\
KP - MMP-9 & 8 & 2.25 & 1.30 \\
\hline & & & \\
\hline K0 - VEGF & 5 & 0.00 & 0.00 \\
KI - VEGF & 6 & 30.53 & 16.65 \\
KP - VEGF & 8 & 5.87 & 1.90 \\
\hline
\end{tabular}

As data from normally distributed dependent variable at $\mathrm{p}<0.05$, then the next test Multivariate analysis of variance (Manova).

Table 2. Test different expression of MMP-9 and VEGF-A between groups (KI and KP) with Test Statistics (Manova)

\begin{tabular}{lccccc}
\hline Groups & \multicolumn{2}{c}{ K1 } & \multicolumn{2}{c}{ KP } & Sig \\
\cline { 2 - 5 } MMP - 9 & Mean & SD & Mean & SD & \\
\cline { 2 - 5 } & 22.51 & 6.03 & 2.25 & 1.30 & 0.000 \\
& Mean & SD & Mean & SD & \\
VEGF- A & 30.53 & 16.65 & 5.87 & 1.90 & 0.001 \\
\hline
\end{tabular}

\section{Cells that express Matrixmetalloproteinase-9 (MMP-9)}

In this study, indirect techniques Amplified Streptavidin Biotin (BSA) immunohistochemistry. The results of the experimental animals incision breast tissue Fig. 1.
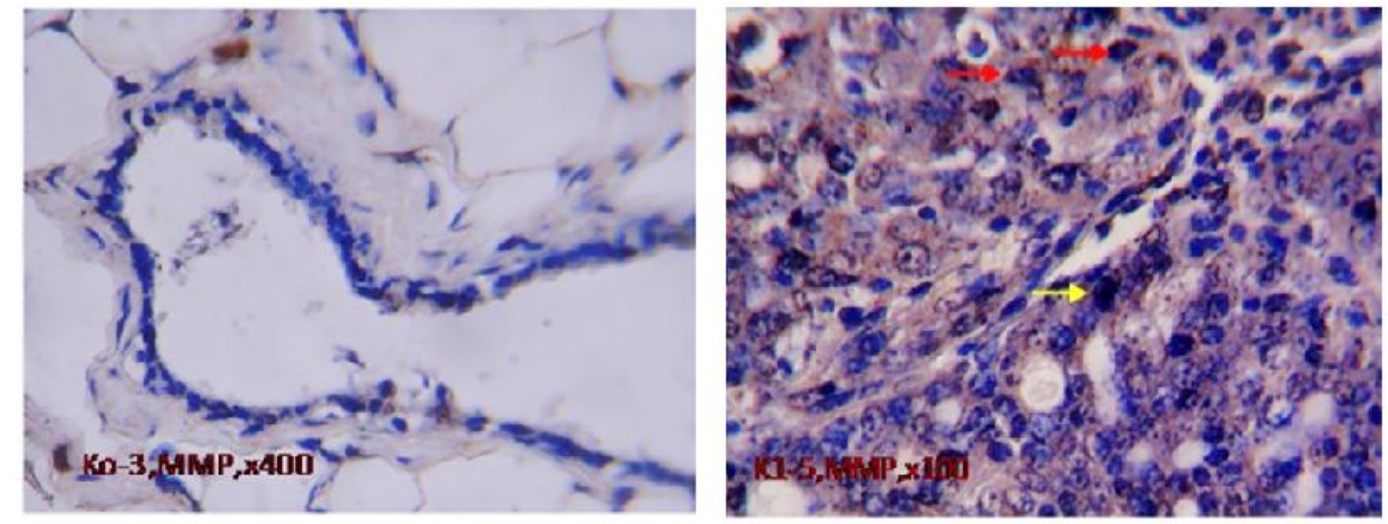

Fig. 1. In this image appears normal breast tissue incision (K0) and breast cancer tissue (K1) experimental animals Sprague Dawley Rattus dyed using Immunohistochemistry (BSA), using a monoclonal antibody (anti-MMP-9) with a 400x magnification photo, 


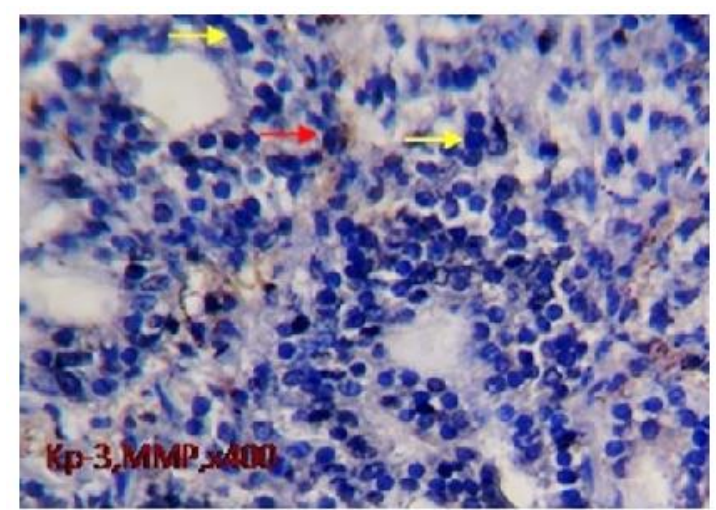

Fig. 2. In this figure appears incision breast tumor tissue of the experimental animals Rattus Sprague Dawley by extracts Cayratia trifolia, dyed using chemical Imunohisto (BSA), using a monoclonal antibody (anti-MMP-9), with 400x magnification. Red arrows indicate cells expressing MMP-9, the yellow arrow shows the cells that did not express MMP-9.

The number of cells that express vascular endothelial growth factor-A (VEGF-A)
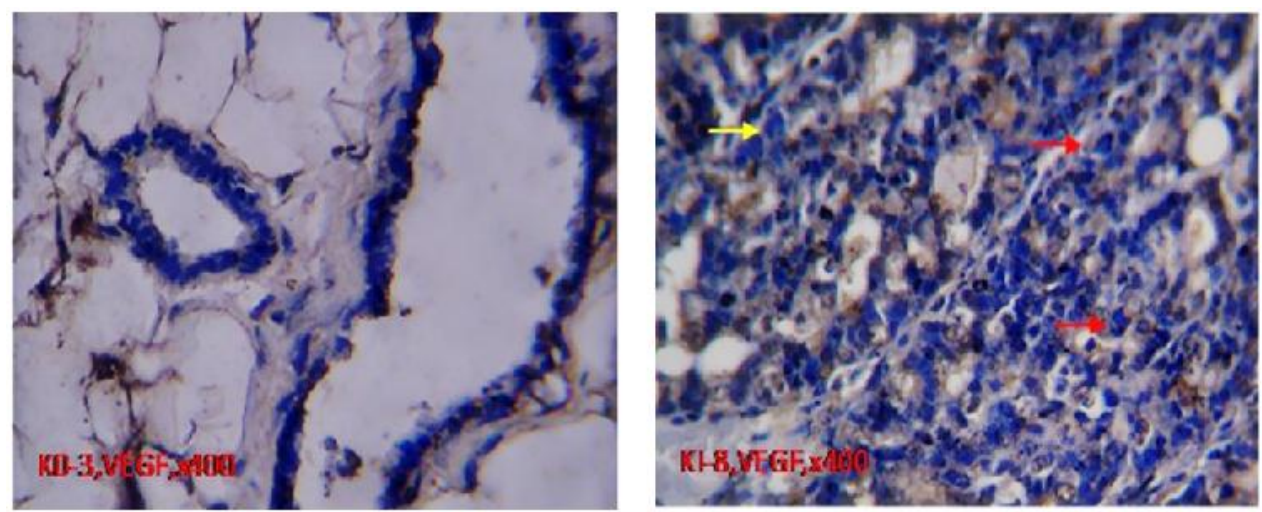

Fig. 3. In this image appears normal breast tissue incision (K0) and breast cancer tissue (K1) experimental animals Sprague Dawley Rattus dyed using Immunohistochemistry (BSA), using a monoclonal antibody (anti-VEGF-A) with a 400x magnification photo ,

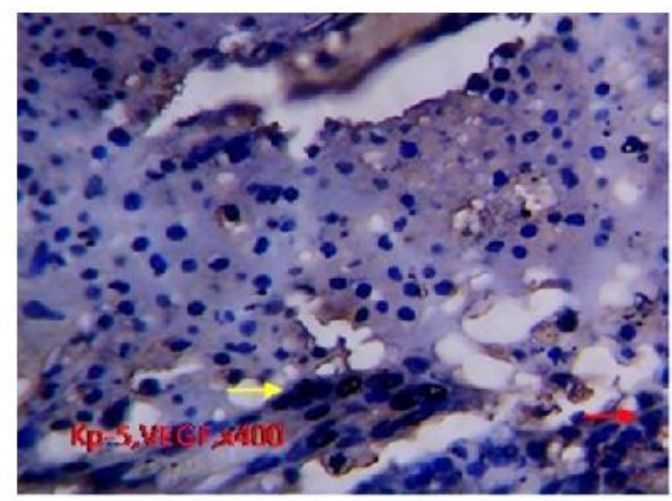

Fig. 4. In this image appears incision breast tumor tissue of the experimental animals Rattus Sprague Dawley by extracts Cayratia trifolia, dyed using Immunohistochemistry (BSA), using a monoclonal antibody (anti-MMP-9), with 400x magnification. Red arrows indicate cells expressing VEGF-A, yellow arrows show cells that do not express VEGF-A. 
Table 4. Correlation between cells expressing MMP-9 and cells expressing VEGF-A.

\begin{tabular}{|c|c|c|c|}
\hline \multicolumn{4}{|c|}{ Correlations } \\
\hline & & MMP_9 & VEGF_A \\
\hline \multirow[t]{3}{*}{ MMP_9 } & Pearson Correlation & 1 & $\overline{917^{* \star}}$ \\
\hline & Sig. (2-tailed) & & ,000 \\
\hline & $\mathrm{N}$ & 14 & 14 \\
\hline \multirow[t]{3}{*}{ VEGF_A } & Pearson Correlation & ,917 ** & 1 \\
\hline & Sig. (2-tailed) & ,000 & \\
\hline & $\mathrm{N}$ & 14 & 14 \\
\hline
\end{tabular}

\section{DISCUSSION}

The incidence of cancer each year has increased. In Indonesia mammary carcinoma is the second most cancer after cervical carcinoma and more than $50 \%$ of patients with breast carcinoma was found in an advanced stage (Kurnia et al 2009). To determine the progression of the cancer cells the researchers looked at the expression of Matrixmetalloproteinase-9 (MMP-9) and Vascular Endothelial Growth Factor-A (VEGF-A). This is because macrophages secrete IFN- $\gamma$ and induce CTL and NK cell activity, thus CTLNK cells are activated by macrophage activates cancer cells. However, cancer cells seek to protect themselves and release MAF, then the macrophages induced into TAM. TAM is then not producing IFN- $\gamma$ so that NK cells and CTL is off, and when CTL and NK cells are not activated, the tumor cells are not attacked by NK cells and CTL. Furthermore, tumor cells release of MMP-9 that aims to undermine the basement membrane so that the tumor cells out into the gland extra tubular and do proliferation into the mass of the tumor and the cancer cells need oxygen and nutrients to the cells the ker The release of VEGF for the process of angiogenesis vascularization (Giraudo et al 2004, Hemati 2010, Quaranta et al 2007, Rundhaug 2003).

To lower the expression of Matrixmetalloproteinase-9 (MMP-9) and Vascular Endothelial Growth Factor (VEG F) in cancer cells can be performed by administering an anti-angiogenic compounds such as stilbenes (such as: piceid, resveratrol, viniferin, and ampelopsin), kaempferol, quercetin (Kumar et al 2011). Some researchers report that kaempferol is a chemical that is used as an anti-angiogenesis in ovarian cancer therapy (Luo et al 2009). These chemical compounds contained in plant Cayratia trifolia L (Domin) as a test to prove the progression of a cancer cell. Researcher using white mice model of breast cancer, particularly a decrease in the expression of Matrixmetallop roteinase9 (MMP-9) and Vascular endothelial growth factor (VEGF).

\section{Effect of ethanol plants Cayratia trifolia L (Domin) the decrease in the number of cells that express MMP-9}

Tests using a statistical test Manova result of breast cancer cells that express MMP-9 between the groups K0 $(\mathrm{X}=0.0000 ; \mathrm{SD}=0.0000)$ with $\mathrm{KI}(\mathrm{X}=22.5167 ; \mathrm{SD}=$ $6.03702)$ represents a a significant difference $(\mathrm{p}<0.05)$. This happens because of DMBA (7,12-Dimethylbenz (a) ant hranceneC20H16 is a potent carcinogen materials and enzymes involved in the metabolism of DMBA is cytocrhome P450 1B1 (CYP1B1) and microsomal epoxide hydrolase (EPHX1), DMBA is converted into its active form, DMBA-3,4-dihydrodiol-1,2epoxide (DMBA-DE). this material will be covalently bound to DNA (DNA adducts) and trigger the occurrence of cancer. CYP1B1 role in metabolism DMBA, was also expressed on organs outside the heart, such as mamma gland. macrophages secrete IFN? and induce a CTL and NK cell activity, thus CTLNK cells are activated by macrophages would damage the cancer cells. But cancer cells seek to protect themselves and release MAF (macrophage Activating Factor), then the macrophages induced into TAM (tumor Associated macrophages). TAM is then not produce IFN- $\gamma$ so that NK cells and CTL is off, and when CTL and NK cells are not activated, the tumor cells are not attacked by NK cells and CTL. Furthermore, cancer cells release of MMP-9 that aims to undermine the basement membrane so that the cancer cells to penetrate the basement membrane resulting in increased expression of MMP-9 and proliferation of cancer cells do become cancerous masses that occur in cancer cell metastasis.

After administering the treatment (KP), the expression of MMP-9 between the groups $\mathrm{K} 0(\mathrm{X}=0.0000 ; \mathrm{SD}=$ $0.0000)$ with the KP group $(X=2.2500 ; \mathrm{SD}=1.29505)$ also showed a significant difference $(\mathrm{p}<0.05)$, in which the experimental animals treated group (who received the plant extract Cayratia trifolia), the expression of MMP-9 is still higher when compared with the normal group of experimental animals. While different test of expression of MMP-9 between the KI (X = 22.5167; SD $=6.03702)$ with the $\mathrm{KP}$ group $(\mathrm{X}=2.2500 ; \mathrm{SD}=$ $1.29505)$ showed significant differences $(p<0.05)$, This shows that the administration of the plant extract Cayratia trifolia L (Domin) within 4 weeks are already able to damage the abnormal cells but not yet completed. This is because the cells that express MMP9 in the treatment group was higher than in the normal group. Plant Cayratia trifolia L (Domin) containing the active compound Resveratrol, delphinidinmal- vidin and quercetin content of these chemical compounds have immunomodulatory effects, which potentially inhibit angiopoitin and FGF and decreased angiogenesis, decrease neovascularization, so metastasis in cancer 
cells can be inhibited (Gao et al 2003, Vetvicka et al 2007).

\section{Effect of ethanol plants Cayratia trifolia L (Domin) the decrease in the number of cells that express VEGF-A}

ANOVA statistical test showed that breast cancer cells that express VEGF-A between the groups $\mathrm{K} 0$ (X = $0.0000 ; \mathrm{SD}=0.0000)$ with $\mathrm{KI}(\mathrm{X}=30.5333$; $\mathrm{SD}=$ $16.65193)$ had a significant difference $(p<0.05)$. This happens because of DMBA (7,12-Dimethylbenz (a) anthranceneC20H16 is a potent carcinogen materials and enzymes involved in the metabolism of DMBA is cytocrhome P450 1B1 (CYP1B1) and microsomal epoxide hydrolase (EPHX1), DMBA is converted to its active form, DMBA -3.4-dihydrodiol-1,2-epoxide (DMBA-DE).

This material will be covalently bound to DNA (DNA adducts) and trigger the occurrence of cancer. CYP1B1 role in DMBA metabolism, it also is expressed in organs outside the heart, such as mamma gland. Macrophages secrete IFN- $\gamma$ and induce CTL and NK cell activity, thus CTLNK cells are activated by macrophages would damage the cancer cells, but not cancer cells seek to protect themselves and release the MAF then macrophages induced into TAM. TAM is then not producing IFN- $\gamma$ so that NK cells and CTL is off, and when CTL and NK cells are not activated, the tumor cells are not attacked by NK cells and CTL. Furthermore, tumor cells do become a mass proliferation of the tumor and the tumor cells need oxygen and nutrients to cancer cells release VEGF to the process of angiogenesis vascularization resulting in increased expression of VEGF. But between batches K0 $(\mathrm{X}=0.0000 ; \mathrm{SD}=0.0000)$ with the $\mathrm{KP}$ group $(\mathrm{X}=$ 5.8750; $\mathrm{SD}=1.89567)$ also showed a significant difference $(p<0.05)$, in which the group treatment of experimental animals (who received the plant extract Cayratia trifolia), VEGF expression was higher when compared with the normal group of experimental animals. Whereas cells expressing VEGF between the groups $\mathrm{KI}(\mathrm{X}=30.5333$; $\mathrm{SD}=16.65193)$ with $\mathrm{KP}$ group $(X=5.8750 ; S D=1.89567)$ showed a significant difference $(\mathrm{p}<0.05)$. It shows that the administration of the plant extract Cayratia trifolia within 4 weeks are already able to damage the abnormal cells but not yet completed. This is because the cells expressing VEGF$\mathrm{A}$ in the treatment group (KP) is lower than the positive control group (K1). Plant Cayratia trifolia L (Domin) containing the active compound Resveratrol, delphinidin/malvidin and Quercetin. These chemical compounds have immunomodulatory effects, which potentially inhibit angiopoitin and FGF and decreased angiogenesis, neovascularization lowered so that the metastatic cancer cells can be inhibited (Gao et al 2003, Vetvicka et al 2007).

This study shows that in animals that did not receive treatment, the number of cells pengekspresi VEGF-A is very high, greater than the experimental animals were treated plant extracts Cayratia trifolia L. It can be seen from the results indicate that the KI (groups of experimental animals are having breast cancer but were not given the plant extract Cayratia trifolia) expressing VEGF (X = 30.5333; SD = 16.6 5193) and KP (groups of experimental animals who have breast cancer who were given extracts of plants Cayratia trifolia) expressing VEGF $(\mathrm{X}=5,8750 ; \mathrm{SD}=1.89567)$.

\section{Analysis of the relationship between the number of cells expressing MMP-9 with the number of cells expressing VEGF-A}

On the results of the test statistic correlation between the number of cells expressing MMP-9 with the number of cells expressing VEGF-A showed a strong relationship and meaning between the number of cells expressing MMP-9 with the number of cells expressing VEGF-A $(r=0.917)$ with $p<0.01$ (correlation test analysis in annex 6B). This shows that the decreased number of cells expressing MMP-9, then the number of cells expressing VEGF also decreased and vice versa.

\section{CONCLUSION}

The ethanol extract of plants Cayratia trifolia L (Domain) can reduce the expression Matrix metalloproteinase-9 (MMP-9) and Vascular Endothelial Growth Factor-A (VEGF-A) in the rat model of breast cancer.

\section{REFERENCES}

Gao X, Dorrah D, Joseph M, George D, Hao J, Robert AC, Subhash CG (2003). Immunomodulatory activity of resveratrol: discrepant in vitro and in vivo immunological effects. J Biochemical Pharmacology 66, 2427-2435

Giraudo E, Inoue M, Hanahan D (2004). An aminobisphosphonate targets MMP-9-expressing macrophages and angiogenesis to impair cervical carcinogenesis. J Clin Invest 114, 623-633

Hemmati HD, Nakano I, Lazareff JA, Masterman-Smith M, Geschwind DH, Bronner-Iraser M, Kornblum HI (2003). Cancerous stem cells can arise from pediatric brain tumors. Proceedings of the National Academy of Sciences USA 100, 15178-15183 
Kumar D, Sunil K, Jyoti G, Renu A, Ankit G (2011). A review on chemical and biological properties of Cayratia trifolia (Linn). Journal NCBI (PMC) Pharmackognosy review 5, 184-188

Kurnia, Suzuki Y, Budiningsih S, Andrijono A, Ramli I, Badri C, Yoshida Y, Nakano T (2009). Nucleolar organizer regions in squamous cell carcinomas of the uterine cervix treated with chemoradiotherapy. Aust Asian J Cancer 8, 93-102

Luo H, Rankin GO, Liu L, Daddysman MK, Jiang BH, Chen YC (2009). Kaempferol inhibits angiogenesis and VEGF expression through both HIF dependent and independent pathways in human ovarian cancer cells. Nutrition and Cancer 61, 554-563

Mayer RJ and Walker HJ (1990). Immunochemical Methods in Cell and Molecular Biology, London, Academic Press Limited

Pratiwi WR, Nurwening ES, Widyarini S (2009). Pengembangan sediaan madu super propoliso sebagai imunomodulator terstandart pada model kanker payudara. Hibah Riset Unggulan Strategis Nasional Universitas Gajah Mada (Rusnas UGM) Tahun Anggaran 2009. Universitas Gajah Mada, Yogyakarta Quaranta M, Daniele A, Coviello M, Venneri MT, Abbate I, Caringella ME, Di Tardo S, Divella R,
Trerotoli P, Di Gennaro M, Schittulli F, Fransvea E, Giannelli G (2007). MMP-2, MMP-9, VEGF and CA 15.3 in breast cancer. Anticancer Res 27, 3593-3600

Roat C, Kumar N, Ramawat KG (2008). Occurrence of stilbenes in unorganized cultures of Cayratia trifolia (L.) DOMIN. Journal of Herbal Medicine and Toxicology 2, 11-15

Rundhaug JE (2003). Matrix metalloproteinases, angiogenesis, and cancer. Clin Cancer Res 9, 551-554

Singh D, Rawat MSM, Semalty A, Semalty M (2012). Quercetin-phospholipid complex: an amorphous pharmaceutical system in herbal drug delivery. Current Drug Discovery Technologies 9, 17-24

Sudiana IK (2005). Teknologi Ilmu Jaringan dan Imunohistokimia, Jakarta, Sagung Seto

Tapas AR, Sakarkar DM, Kakde RB (2008). Flavonoids as nutraceuticals: a review. Trop J Pharm Res 7, 10891099

Vetvicka V, Tomas V, Sujata SO, Aruna V, Zuzana V, Jana V (2007). Glucan and resveratrol complex possible synergistic effects on immune system. Biomed Pap Med Fac Univ Palacky Olomouc Czech Repub 151, 41-46 